Published in final edited form as:

Pharm Res. 2011 December ; 28(12): 3043-3049. doi:10.1007/s11095-011-0526-2.

\title{
MicroRNAs and cancer therapeutics
}

\author{
Man Lung Yeung ${ }^{1}$ and Kuan-Teh Jeang ${ }^{2, *}$ \\ ${ }^{1}$ Department of Microbiology, the University of Hong Kong, SAR, China \\ ${ }^{2}$ Molecular Virology Section, Laboratory of Molecular Microbiology National Institute of Allergy \\ and Infectious Diseases, National Institutes of Health, Bethesda, Maryland 20892-0460, USA
}

\begin{abstract}
MicroRNAs (miRNAs) are small physiological non-coding RNAs that regulate gene expression through an RNA interference (RNAi) mechanism. The expression of miRNAs is tightly controlled both spatially and temporally. Aberrant miRNA expression has been correlated with various cancers. Recent findings suggest that some miRNAs can function as tumor suppressors or oncogenes. In model experiments, the cancer phenotype of some cells can be reverted to normal when the cells are treated with miRNA mimics or inhibitors. Here, we discuss in brief the potential utility of miRNA-based cancer therapy as well as the current limitations thwarting their useful clinical application.
\end{abstract}

\section{Introduction}

RNA interference (RNAi) is a physiological mechanism that was initially reported as "posttranscriptional gene silencing" (PTGS) in plants. It plays important regulatory roles in diverse biological processes including apoptosis, developmental timing, signal transduction, cell proliferation and immune defenses [reviewed in (1-4)]. In eukaryotes, one form of gene specific silencing uses the incorporation of $18-25$ nucleotides (nts) small RNAs, called miRNA, into the RNAi pathway. The biogenesis of miRNAs progresses through a series of processing steps. First, a highly-structured RNA (pri-miRNA), is transcribed by RNA polymerase II (RNAP II). Within the nucleus, the pri-miRNA is cleaved by the microprocessor, a protein complex that contains a ribonuclease (Drosha) and a RNA binding protein (DGCR8), to a $\sim 70$ nt stem-loop RNA intermediate called pre-miRNA. The premiRNA is exported by Exportin 5 into the cytoplasm. Once in the cytoplasm, the hairpin of the pre-miRNA is removed by another ribonuclease (Dicer) to generate a double-stranded mature miRNA. The mature miRNA is then bound to a double-strand RNA binding protein [TAR RNA-binding protein (TRBP)] (5) and organized into a large multi-protein complex called the RNA-induced silencing complex (RISC). One strand of the double-stranded miRNA (guide strand) is incorporated into the complex. The other strand (passenger strand) is degraded. The miRNA-loaded RISC can then silence target mRNAs through imperfect complementarity between the mRNA and the guide miRNA. Early observations suggested that perfect complementary of the $5^{\prime}$ ends of miRNAs nucleotides $2-7$, termed seed sequence, is important for function (6). However, new findings reveal that the central region (7) and the $3^{\prime}$ UTR $(8,9)$ of the miRNA also play important roles in target recognition. The miRNA-RISC targeted mRNAs is silenced through inhibition of translation $(10,11)$ or mRNA degradation $(12,13)$. The biological importance of the RNAi mechanism is supported by findings that the perturbed expression of miRNAs or the components of the RNAi machinery results in the development of various diseases (14-21).

*To whom correspondence should be addressed: Building 4, Room 306, 9000 Rockville Pike, Bethesda, MD 20892-0460, USA, Tel: 301-496-6680; Fax: 301-480-3686, kj7e@ nih.gov. 


\section{Aberrant miRNA expression and oncogenesis}

MiRNA expression is tightly regulated both spatially and temporally (Figure 1). A role for miRNA in tumorigenesis was first reported by Calin et al. in describing a chromosome region containing miR-15a and miR-16-1 which is frequently deleted or translocated in chronic lymphocytic leukemia (CLL) (22). Subsequently, the roles of miRNAs in various cancers have been investigated. Some investigators have found a global down-regulation of miRNA levels in tumor cells (23). This down-regulation is partially explained by the fact that some tumor suppressors and oncogenes can modulate the miRNA-promoters' activity. Indeed, tumor suppressors and oncogenes, including p53 and c-Myc which are transcriptional activators, have been shown experimentally to modulate the activities of miRNA promoters $(24,25)$. A bioinformatics analysis estimated that over $46 \%$ of the deduced promoters for 326 human miRNAs were found to have potential p53 binding sites (24). Others have reported specific miRNA signature profiles in different tumor types (23) and have demonstrated the usefulness of miRNA changes for predicting cancer prognosis (26) and therapeutic responses (27). Moreover, the deletion, downregulation, and/or mutation of key RNAi components, including Dicer, Drosha, Exportin 5, TRBP and Ago2 have been correlated with various types of cancer (14-21). Collectively, the extant data support that miRNA changes can contribute to oncogenesis and that it is important to elucidate how individual miRNA changes predispose cells to transformation.

A well-characterized miRNA whose dysregulated expression correlates with tumorigenesis is miR-155. Elevated miR-155 expression was found associated with various cancers (2832 ), and a role for miR-155 in modulating host immune responses has also been described (33). Interestingly, the oncogenic Kaposi's sarcoma-associated herpesvirus (KSHV) encodes a miRNA called miR-k12-11 which shares an identical seed sequence with miR-155 (34, 35). Thus, it appears that some oncogenic cellular miRNAs and oncogenic virus-encoded miRNAs may employ common pathways for tumorigenesis. However, other transforming viruses such as human T-cell leukemia virus type 1 (HTLV-1) do not encode oncogenic miRNAs and instead seem to dysregulate cellular metabolism by modulating the promoterexpression of key cellular miRNAs $(36,37)$. HTLV-1 uses its viral oncoprotein, Tax, to induce miR-130b and miR-93 expression. Over-expression of miR-130b and miR-93 represses the expression of a cellular tumor suppressor protein, TP53INP1, and hence induces tumorigenicity $(37,38)$.

Many studies have shown that miRNAs can have oncogenic or tumor suppressing functions. For example, a well-characterized oncogenic miRNAs (oncomirs) is miR-21 which regulates the expression of the anti-apoptotic protein bcl-2 (39). It has been shown that the sequestration of miR-21 by anti-miR-21 in breast cancer MCF-7 cells enhanced apoptosis and suppressed cell growth. Replenishing miRNA expression in certain cancers has been found to be effective in controlling cell growth. A recent finding suggests that p53 can activate the expression of miR-34 (40) and that the transfection or transduction of miR-34 into p53-deficient gastric cancer cells was able to target bcl-2, Notch and HMGA2 expression and inhibit cell growth and/or induce apoptosis (41). Increasingly, it is recognized that miRNAs can target oncogenes and tumor suppressor genes (42). In animal models, modulation of certain miRNAs expression controls the size and the metastatic potential of specific tumors (43-52) (see Table 2). This recognition has led to nascent clinical trials using miRNA inhibitors to sequester cellular miRNAs such as miR-122 which is essential for Hepatitis $\mathrm{C}$ virus (HCV) replication with the hope of ameliorating the development of hepatomas (53-55). Additionally, efforts have been made to identify small molecules that suppress the function of oncogenic miRNAs possibly reversing their tumorigenesis phenotype (36). Time will tell whether miRNA-based therapy may represent a useful new way to treat cancer. 


\section{In vivo delivery of small RNAs}

Small RNA-based therapy can offer some advantage over conventional cancer drug treatment. Because a single miRNA can target many mRNAs, miRNA-based therapy could silence a broad array of genes, and by doing so, this method may potentially increase the efficiency of controlling the growth or spread of cancers. Also, the relatively low cost of synthesis, their small molecular size, and the ease of design, all make small RNA therapy appealing. However, similar to many other treatment modalities, the major hurdle to using small RNA-based therapy in vivo is the efficiency of focused delivery to specific cells.

Delivery of small RNA in vivo has been attempted using various methods (Table 1). Each has advantages and disadvantages. The earliest attempt to deliver small RNA in vivo involved direct hydrodynamic injection of siRNA intravenously (56). The injected siRNA accumulated in the hepatocytes of the mice silencing the expression of Fas. As a result, the injected mouse's liver was successfully protected from the development of fulminant hepatitis and fibrosis. However, the hydrodynamic methodology is impractical clinically due to the requirement of injecting large quantities of small RNAs. Furthermore, naked siRNA could be relatively unstable due to the presence of endogenous RNases. Thus, high functional efficacy at desired sites remains a major challenge.

Lipid-based nucleic acids delivery has been widely used in vitro. The negatively charged nucleic acids are protected from the environment by interacting with the cationic lipids to form liposomes. The liposomes can fuse with the cell membrane, releasing the nucleic acids into the cells. Although cationic lipid-complexed siRNAs have been delivered effectively into cells, they are highly immunogenic (57). Other non-charged nanoparticles, such as biodegradable polymers which induce less inflammation could possibly reduce this problem. The application of in vivo delivery of mi-/si-RNAs will be discussed below.

Viral vectors represent another approach for small RNA delivery. Typically, viruses are engineered to be replication-defective, preventing them from propagating an undesired spread of infection. The precursor forms of mi-/sh-RNA are expressed and processed by the cellular machinery after transduction of cells by viral vectors carrying the appropriate mi-/ sh-RNA expression cassettes. The advantages of this method include the ability to establish long-term knock down of targeted mRNAs and the high efficiency transduction using viral particles of many types of cell. However, an adverse effect can arise due to the integration of the viral vector into host cell DNA. Random insertion of the transduced viral vector could disrupt crucial genes and/or potentially activate harmful cellular proto-oncogenes (58). Lastly, undesired immune responses induced by the viral vectors may be harmful and should also be carefully evaluated.

The stability, toxicity, immunogenicity and durability of the above-mentioned delivery methods have hindered the progression of these approaches to clinical usage. The recent development of nanoparticles may address most of the problems. Generally, nanoparticles are positively-charged particles with diameters of $\sim 50-70 \mathrm{~nm}$. They elicit minimal inflammatory responses. The negatively charged mi-/si-RNAs are completely buried inside the electrolyte core formed by the nanoparticles. This significantly increases the stability of the embedded mi-/si-RNAs. Also, the protective core of the nanoparticles allows relatively slow release of small molecules for continuous knock-down of specific gene expression.

Recent clinical trials using the nanoparticles-siRNA delivery approach for treating solid cancers have shown promising results. The first nanoparticle formulation of siRNA underwent phase I clinic trial in 2008; it is called CALAA-01 (59). The trial employed several kinds of nanoparticles including cyclodextrin-containing polymer (CDP), polyethylene glycol (PEG) steric stabilization agent and human transferrin (hTf) as a 
targeting ligand for binding to transferrin receptors (TfR). The CALAA-01 agent was complexed with siRNAs designed to target ribonucleotide reductase M2 (RRM2), a gene involved in DNA replication that is commonly deregulated in many cancers. It has been shown that the in vivo delivery of a siRNA against RRM2 reduced the proliferative activity of a broad spectrum of human, mouse, rat and monkey cancers with minimal immune response or toxicity $(60,61)$.

CALAA-01 is the first siRNA nanoparticle to be therapeutically tried in humans (59). The promising results from this trial suggests that further clinical studies of the in vivo mi-/siRNA nanoparticles delivery system including the new RNAi agents Atu027 and ALN-VSP may be warranted. For a more detailed review of preclinical and clinical development of RNAi drugs, the readers are referred to an excellent review article (62).

Dysregulated expression of miRNA correlates with the disease status of cancers. Indeed, a few recent studies have reported the successfully reversal of the cancer phenotype by nanoparticle-mediated delivery of miRNAs in animal models (see below and Table 2). It has been suggested that the tumor endothelium can upregulate miR-132 expression by activating cAMP response element-binding protein (CREB) through a vascular endothelial growth factor receptor 2 (VEGFR-2) dependent pathway (51). The upregulated miR-132 can act as an angiogenic switch suppressing endothelial p120RasGAP expression, leading to Ras activation and the induction of neovascularization (63). By using vessel-targeted nanoparticle delivery of anti-miR-132, investigators have successfully sequestered miR-132 in the tumor endothelium (51). As a result of this approach, p120RasGAP expression level was restored, and this was accompanied by suppressed angiogenesis and decreased tumor burden in an orthotopic xenograft mouse model of human breast carcinoma. In another study, the intravenous administration of a miR-16 mimic complexed with atelocollagen strongly inhibited the development of human prostate metastatic tumors in the bone of mice (48). The anti-tumor effect of the nanoparticle formulation can be enhanced when complexed with multiple small RNAs. A recent study using liposome-polycation-hyaluronic acid (LPH) nanoparticle formulation modified with tumor-targeting single-chain antibody fragment ( $\mathrm{scFv}$ ) nanoparticles delivered siRNAs and miR-34a into lung cancer metastases (52). The delivered siRNA and miRNA efficiently downregulated the targeted genes (cMyc/MDM2/VEGF/survivin/MAPK family) and hence controlled the progressin of the lung tumor. The capacity to deliver siRNA and/or miRNA with a single formulation significantly increases the flexibility of therapeutic uses of mi-/si-RNA.

\section{Other possible side effects and future challenges}

Many concerns need to be addressed before miRNA-based therapy can be safely applied to clinical settings. First, one should be cautious regarding the specificity (or off-target effect) of miRNA-based gene silencing because a single miRNA can target many mRNAs (64). Choosing a miRNA which targets many genes in the same pathway may consolidate the silencing effect and diminish the magnitude of off-target effects. It should be noted that a single mRNA can also be targeted by multiple miRNAs. Utilizing a combination of miRNAs that converge on a single mRNA may lower the concentration of miRNAs required for silencing and enhance the specificity of silencing.

Second, double-stranded RNA can trigger the innate immune system through activation of double-stranded RNA (dsRNA)-dependent protein kinase R or retinoic acid inducible gene-I (57). The strength of activation of the innate response is determined by the amount, the length, and the sequence composition of the RNA. Minimal activation was observed with double-stranded RNA with size $<30$ nucleotides. However, high amounts of uracil and guanine rich sequence content of small RNAs were reported to be able to elicit significant 
immune response (57). Future development of small RNA-based therapy requires careful design of sequence composition. Also, the use of modified nucleotides, such as LNA, will lower the amount needed for small RNA-based therapy and decrease the likelihood of innate immune activation.

Third, although viral delivery of small RNA is attractive because of its high efficiency, its local administration, and its persistence, elicit particular safety concerns. Efficient delivery into the host may also elicit unpredictable hyper immune reactions, and effective vector entry into cells also means abundant viral vector DNA integration into the host genome (65). An illustration of unwanted and unexpected side effects came from an early animal model using adeno-associated virus to deliver shRNA that targeted the expression of a human a-1 antitrypsin mRNA. In that study, overexpression of shRNA led to the oversaturation of the cell's RNA-transporter protein, Exportin-5, and induced hepatotoxicity in the experimental animals (66). Hence, rather than using constitutive high efficiency expression of shRNAs, a modified approach using an inducible expression system for shRNA in the context of a viral vector could permit a more regulated method that uses just the needed amount of shRNA during a targeted timeframe for controlled knock down of specific genes (67-69).

Finally, the effectiveness of siRNA/miRNA-mediated silencing may be limited by several additional cellular factors including RNA-binding proteins that may act as RNAi suppressors and which may also be able to shield targeted RNAs from complementarity driven recognition by si-/mi-RNA. How intracellular RNA-binding proteins and RNAmodifying enzymes including RNA helicases may impede or enhance RNAi effects warrants further study.

\section{Concluding remarks}

RNAi represents a biological mechanism that in principle could be exploited to provide rapid and efficient down-modulation of gene expression. While the fundamental bases for siRNA- or miRNA- mediated gene silencing are becoming clearer, the challenges of applying these small RNA-based approaches to the therapy of diseases including cancers are non-trivial. Recent news that a large drug company Roche has retrenched or eliminated its commitment to RNAi research (http://pubs.acs.org/cen/news/88/i48/8848notw6.html) illustrates some of the real world obstacles to the application of miRNA and siRNA. As outlined above, the clinical uses of the fundamental principles behind RNAi require additional research breakthroughs that can allow investigators to deliver small therapeutic RNAs more efficiently, more specifically, and more durably for gene silencing in vivo.

\section{Abbreviations}

$\begin{array}{ll}\text { miRNAs } & \text { MicroRNAs } \\ \text { RNAi } & \text { RNA interference } \\ \text { PTGS } & \text { Post-transcriptional gene silencing } \\ \text { nts } & \text { nucleotides } \\ \text { RNAP II } & \text { RNA polymerase II } \\ \text { TRBP } & \text { TAR RNA-binding protein } \\ \text { RISC } & \text { RNA-induced silencing complex } \\ \text { CLL } & \text { chronic lymphocytic leukemia } \\ \text { KSHV } & \text { Kaposi's sarcoma-associated herpesvirus }\end{array}$




$\begin{array}{ll}\text { HTLV-1 } & \text { Human T-cell Leukemia Virus type 1 } \\ \text { oncomirs } & \text { oncogenic miRNAs } \\ \text { HCV } & \text { Hepatitis C virus } \\ \text { CDP } & \text { cyclodextrin-containing polymer } \\ \text { PEG } & \text { polyethylene glycol } \\ \text { hTf } & \text { human transferrin } \\ \text { TfR } & \text { targeting ligand for binding to transferrin receptors } \\ \text { RRM2 } & \text { ribonucleotide reductase M2 } \\ \text { CREB } & \text { cAMP response element-binding } \\ \text { VEGFR-2 } & \text { vascular endothelial growth factor receptor 2 } \\ \text { LPH } & \text { liposome-polycation-hyaluronic acid } \\ \text { SCFv } & \text { single-chain antibody fragment } \\ \text { dsRNA } & \text { double-stranded RNA }\end{array}$

\section{References}

1. Bartel DP. MicroRNAs: Target Recognition and Regulatory Functions. Cell. 2009; 136:215-233. [PubMed: 19167326]

2. Carthewand EJ, Sontheimer RW. Origins and Mechanisms of miRNAs and siRNAs. Cell. 2009; 136:642-655. [PubMed: 19239886]

3. Kim VN, Han J, Siomi MC. Biogenesis of small RNAs in animals. Nat Rev Mol Cell Bio. 2009; 10:126-139. [PubMed: 19165215]

4. Smibertand EC, Lai P. Lessons from microRNA mutants in worms, flies and mice. Cell Cycle. 2008; 7:2500-2508. [PubMed: 18719388]

5. Gatignol A, Buckler-White A, Berkhout B, Jeang KT. Characterization of a human TAR RNAbinding protein that activates the HIV-1 LTR. Science. 1991; 251:1597-1600. [PubMed: 2011739]

6. Brodersenand O, Voinnet P. Revisiting the principles of microRNA target recognition and mode of action. Nat Rev Mol Cell Biol. 2009; 10:141-148. [PubMed: 19145236]

7. Shin C, Nam JW, Farh KK, Chiang HR, Shkumatava A, Bartel DP. Expanding the microRNA targeting code: functional sites with centered pairing. Mol Cell. 2010; 38:789-802. [PubMed: 20620952]

8. Robinsand WH, Press H. Human microRNAs target a functionally distinct population of genes with AT-rich 3' UTRs. Proc Natl Acad Sci U S A. 2005; 102:15557-15562. [PubMed: 16230613]

9. Sun G, Li H, Rossi JJ. Sequence context outside the target region influences the effectiveness of miR-223 target sites in the RhoB 3'UTR. Nucleic Acids Res. 2010; 38:239-252. [PubMed: 19850724]

10. Wakiyama M, Takimoto K, Ohara O, Yokoyama S. Let-7 microRNA-mediated mRNA deadenylation and translational repression in a mammalian cell-free system. Genes Dev. 2007; 21:1857-1862. [PubMed: 17671087]

11. Chendrimada TP, Finn KJ, Ji X, Baillat D, Gregory RI, Liebhaber SA, Pasquinelli AE, Shiekhattar R. MicroRNA silencing through RISC recruitment of eIF6. Nature. 2007; 447:823-828. [PubMed: 17507929]

12. Fabian MR, Sonenberg N, Filipowicz W. Regulation of mRNA translation and stability by microRNAs. Annu Rev Biochem. 2010; 79:351-379. [PubMed: 20533884]

13. Wu L, Fan J, Belasco JG. MicroRNAs direct rapid deadenylation of mRNA. Proc Natl Acad Sci U S A. 2006; 103:4034-4039. [PubMed: 16495412] 
14. Merritt WM, Lin YG, Han LY, Kamat AA, Spannuth WA, Schmandt R, Urbauer D, Pennacchio LA, Cheng JF, Nick AM, Deavers MT, Mourad-Zeidan A, Wang H, Mueller P, Lenburg ME, Gray JW, Mok S, Birrer MJ, Lopez-Berestein G, Coleman RL, Bar-Eli M, Sood AK. Dicer, Drosha, and outcomes in patients with ovarian cancer. N Engl J Med. 2008; 359:2641-2650. [PubMed: 19092150]

15. Karube Y, Tanaka H, Osada H, Tomida S, Tatematsu Y, Yanagisawa K, Yatabe Y, Takamizawa J, Miyoshi S, Mitsudomi T, Takahashi T. Reduced expression of Dicer associated with poor prognosis in lung cancer patients. Cancer Sci. 2005; 96:111-115. [PubMed: 15723655]

16. Carmell MA, Xuan Z, Zhang MQ, Hannon GJ. The Argonaute family: tentacles that reach into RNAi, developmental control, stem cell maintenance, and tumorigenesis. Genes Dev. 2002; 16:2733-2742. [PubMed: 12414724]

17. Sun J, Zheng SL, Wiklund F, Isaacs SD, Li G, Wiley KE, Kim ST, Zhu Y, Zhang Z, Hsu FC, Turner AR, Stattin P, Liu W, Kim JW, Duggan D, Carpten J, Isaacs W, Gronberg H, Xu J, Chang BL. Sequence variants at 22q13 are associated with prostate cancer risk. Cancer Res. 2009; 69:1015. [PubMed: 19117981]

18. Horikawa Y, Wood CG, Yang H, Zhao H, Ye Y, Gu J, Lin J, Habuchi T, Wu X. Single nucleotide polymorphisms of microRNA machinery genes modify the risk of renal cell carcinoma. Clin Cancer Res. 2008; 14:7956-7962. [PubMed: 19047128]

19. Yang H, Dinney CP, Ye Y, Zhu Y, Grossman HB, Wu X. Evaluation of genetic variants in microRNA-related genes and risk of bladder cancer. Cancer Res. 2008; 68:2530-2537. [PubMed: 18381463]

20. Ye Y, Wang KK, Gu J, Yang H, Lin J, Ajani JA, Wu X. Genetic variations in microRNA-related genes are novel susceptibility loci for esophageal cancer risk. Cancer Prev Res (Phila). 2008; 1:460-469. [PubMed: 19138993]

21. Clague J, Lippman SM, Yang H, Hildebrandt MA, Ye Y, Lee JJ, Wu X. Genetic variation in MicroRNA genes and risk of oral premalignant lesions. Mol Carcinog. 2010; 49:183-189. [PubMed: 19851984]

22. Calin GA, Dumitru CD, Shimizu M, Bichi R, Zupo S, Noch E, Aldler H, Rattan S, Keating M, Rai K, Rassenti L, Kipps T, Negrini M, Bullrich F, Croce CM. Frequent deletions and down-regulation of micro- RNA genes miR15 and miR16 at 13q14 in chronic lymphocytic leukemia. Proc Natl Acad Sci U S A. 2002; 99:15524-15529. [PubMed: 12434020]

23. Lu J, Getz G, Miska EA, Alvarez-Saavedra E, Lamb J, Peck D, Sweet-Cordero A, Ebert BL, Mak RH, Ferrando AA, Downing JR, Jacks T, Horvitz HR, Golub TR. MicroRNA expression profiles classify human cancers. Nature. 2005; 435:834-838. [PubMed: 15944708]

24. Xi Y, Shalgi R, Fodstad O, Pilpel Y, Ju J. Differentially regulated micro-RNAs and actively translated messenger RNA transcripts by tumor suppressor p53 in colon cancer. Clin Cancer Res. 2006; 12:2014-2024. [PubMed: 16609010]

25. O’Donnell KA, Wentzel EA, Zeller KI, Dang CV, Mendell JT. c-Myc-regulated microRNAs modulate E2F1 expression. Nature. 2005; 435:839-843. [PubMed: 15944709]

26. Iorio MV, Visone R, Di Leva G, Donati V, Petrocca F, Casalini P, Taccioli C, Volinia S, Liu CG, Alder H, Calin GA, Menard S, Croce CM. MicroRNA signatures in human ovarian cancer. Cancer Res. 2007; 67:8699-8707. [PubMed: 17875710]

27. Calin GA, Ferracin M, Cimmino A, Di Leva G, Shimizu M, Wojcik SE, Iorio MV, Visone R, Sever NI, Fabbri M, Iuliano R, Palumbo T, Pichiorri F, Roldo C, Garzon R, Sevignani C, Rassenti L, Alder H, Volinia S, Liu CG, Kipps TJ, Negrini M, Croce CM. A MicroRNA signature associated with prognosis and progression in chronic lymphocytic leukemia. N Engl J Med. 2005; 353:1793-1801. [PubMed: 16251535]

28. Iorio MV, Ferracin M, Liu CG, Veronese A, Spizzo R, Sabbioni S, Magri E, Pedriali M, Fabbri M, Campiglio M, Menard S, Palazzo JP, Rosenberg A, Musiani P, Volinia S, Nenci I, Calin GA, Querzoli P, Negrini M, Croce CM. MicroRNA gene expression deregulation in human breast cancer. Cancer Res. 2005; 65:7065-7070. [PubMed: 16103053]

29. Fulci V, Chiaretti S, Goldoni M, Azzalin G, Carucci N, Tavolaro S, Castellano L, Magrelli A, Citarella F, Messina M, Maggio R, Peragine N, Santangelo S, Mauro FR, Landgraf P, Tuschl T, Weir DB, Chien M, Russo JJ, Ju J, Sheridan R, Sander C, Zavolan M, Guarini A, Foa R, Macino 
G. Quantitative technologies establish a novel microRNA profile of chronic lymphocytic leukemia. Blood. 2007; 109:4944-4951. [PubMed: 17327404]

30. Lawrie CH, Soneji S, Marafioti T, Cooper CD, Palazzo S, Paterson JC, Cattan H, Enver T, Mager R, Boultwood J, Wainscoat JS, Hatton CS. MicroRNA expression distinguishes between germinal center B cell-like and activated B cell-like subtypes of diffuse large B cell lymphoma. Int J Cancer. 2007; 121:1156-1161. [PubMed: 17487835]

31. Greither T, Grochola LF, Udelnow A, Lautenschlager C, Wurl P, Taubert H. Elevated expression of microRNAs 155, 203, 210 and 222 in pancreatic tumors is associated with poorer survival. Int J Cancer. 2010; 126:73-80. [PubMed: 19551852]

32. Habbe N, Koorstra JB, Mendell JT, Offerhaus GJ, Ryu JK, Feldmann G, Mullendore ME, Goggins MG, Hong SM, Maitra A. MicroRNA miR-155 is a biomarker of early pancreatic neoplasia. Cancer Biol Ther. 2009; 8:340-346. [PubMed: 19106647]

33. Rodriguez A, Vigorito E, Clare S, Warren MV, Couttet P, Soond DR, van Dongen S, Grocock RJ, Das PP, Miska EA, Vetrie D, Okkenhaug K, Enright AJ, Dougan G, Turner M, Bradley A. Requirement of bic/microRNA-155 for normal immune function. Science. 2007; 316:608-611. [PubMed: 17463290]

34. Nairand M, Zavolan V. Virus-encoded microRNAs: novel regulators of gene expression. Trends Microbiol. 2006; 14:169-175. [PubMed: 16531046]

35. Gottwein E, Mukherjee N, Sachse C, Frenzel C, Majoros WH, Chi JT, Braich R, Manoharan M, Soutschek J, Ohler U, Cullen BR. A viral microRNA functions as an orthologue of cellular miR-155. Nature. 2007; 450:1096-1099. [PubMed: 18075594]

36. Watashi K, Yeung ML, Starost MF, Hosmane RS, Jeang KT. Identification of small molecules that suppress microRNA function and reverse tumorigenesis. J Biol Chem. 2010

37. Yeung ML, Yasunaga J, Bennasser Y, Dusetti N, Harris D, Ahmad N, Matsuoka M, Jeang KT. Roles for microRNAs, miR-93 and miR-130b, and tumor protein 53-induced nuclear protein 1 tumor suppressor in cell growth dysregulation by human T-cell lymphotrophic virus 1. Cancer Res. 2008; 68:8976-8985. [PubMed: 18974142]

38. Ma S, Tang KH, Chan YP, Lee TK, Kwan PS, Castilho A, Ng I, Man K, Wong N, To KF, Zheng BJ, Lai PB, Lo CM, Chan KW, Guan XY. miR-130b Promotes CD133(+) liver tumor-initiating cell growth and self-renewal via tumor protein 53-induced nuclear protein 1. Cell Stem Cell. 2010; 7:694-707. [PubMed: 21112564]

39. Si ML, Zhu S, Wu H, Lu Z, Wu F, Mo YY. miR-21-mediated tumor growth. Oncogene. 2007; 26:2799-2803. [PubMed: 17072344]

40. He L, He X, Lim LP, de Stanchina E, Xuan Z, Liang Y, Xue W, Zender L, Magnus J, Ridzon D, Jackson AL, Linsley PS, Chen C, Lowe SW, Cleary MA, Hannon GJ. A microRNA component of the p53 tumour suppressor network. Nature. 2007; 447:1130-1134. [PubMed: 17554337]

41. Ji Q, Hao X, Meng Y, Zhang M, Desano J, Fan D, Xu L. Restoration of tumor suppressor miR-34 inhibits human p53-mutant gastric cancer tumorspheres. BMC Cancer. 2008; 8:266. [PubMed: 18803879]

42. Cho WCS. MicroRNAs in cancer -- from research to therapy. Biochimica et Biophysica Acta (BBA) - Reviews on Cancer. 2010; 1805:209-217.

43. Elyakim E, Sitbon E, Faerman A, Tabak S, Montia E, Belanis L, Dov A, Marcusson EG, Bennett CF, Chajut A, Cohen D, Yerushalmi N. hsa-miR-191 is a candidate oncogene target for hepatocellular carcinoma therapy. Cancer Res. 2010; 70:8077-8087. [PubMed: 20924108]

44. Kumar MS, Erkeland SJ, Pester RE, Chen CY, Ebert MS, Sharp PA, Jacks T. Suppression of nonsmall cell lung tumor development by the let-7 microRNA family. Proc Natl Acad Sci U S A. 2008; 105:3903-3908. [PubMed: 18308936]

45. Ma L, Reinhardt F, Pan E, Soutschek J, Bhat B, Marcusson EG, Teruya-Feldstein J, Bell GW, Weinberg RA. Therapeutic silencing of miR-10b inhibits metastasis in a mouse mammary tumor model. Nat Biotechnol. 2010; 28:341-347. [PubMed: 20351690]

46. Zhang XP, Ladd A, Dragoescu E, Budd WT, Ware JL, Zehner ZE. MicroRNA-17-3p is a prostate tumor suppressor in vitro and in vivo, and is decreased in high grade prostate tumors analyzed by laser capture microdissection. Clin Exp Metastas. 2009; 26:965-979. 
47. Mercatelli N, Coppola V, Bonci D, Miele F, Costantini A, Guadagnoli M, Bonanno E, Muto G, Frajese GV, De Maria R, Spagnoli LG, Farace MG, Ciafre SA. The Inhibition of the Highly Expressed Mir-221 and Mir-222 Impairs the Growth of Prostate Carcinoma Xenografts in Mice. Plos One. 2008; 3

48. Takeshita F, Patrawala L, Osaki M, Takahashi R, Yamamoto Y, Kosaka N, Kawamata M, Kelnar K, Bader AG, Brown D, Ochiya T. Systemic Delivery of Synthetic MicroRNA-16 Inhibits the Growth of Metastatic Prostate Tumors via Downregulation of Multiple Cell-cycle Genes. Mol Ther. 2010; 18:181-187. [PubMed: 19738602]

49. Li JS, Huang HZ, Sun LJ, Yang M, Pan CB, Chen WL, Wu DH, Lin ZY, Zeng CX, Yao YD, Zhang P, Song EW. MiR-21 Indicates Poor Prognosis in Tongue Squamous Cell Carcinomas as an Apoptosis Inhibitor. Clinical Cancer Research. 2009; 15:3998-4008. [PubMed: 19509158]

50. Kota J, Chivukula RR, O’Donnell KA, Wentzel EA, Montgomery CL, Hwang HW, Chang TC, Vivekanandan P, Torbenson M, Clark KR, Mendell JR, Mendell JT. Therapeutic microRNA Delivery Suppresses Tumorigenesis in a Murine Liver Cancer Model. Cell. 2009; 137:1005-1017. [PubMed: 19524505]

51. Anand S, Majeti BK, Acevedo LM, Murphy EA, Mukthavaram R, Scheppke L, Huang M, Shields DJ, Lindquist JN, Lapinski PE, King PD, Weis SM, Cheresh DA. MicroRNA-132-mediated loss of p120RasGAP activates the endothelium to facilitate pathological angiogenesis. Nat Med. 2010; 16:909-U109. [PubMed: 20676106]

52. Chen YC, Zhu XD, Zhang XJ, Liu B, Huang L. Nanoparticles Modified With Tumor-targeting scFv Deliver siRNA and miRNA for Cancer Therapy. Mol Ther. 2010; 18:1650-1656. [PubMed: 20606648]

53. Jopling CL. Regulation of hepatitis C virus by microRNA-122. Biochem Soc Trans. 2008; 36:1220-1223. [PubMed: 19021529]

54. Jopling CL, Yi M, Lancaster AM, Lemon SM, Sarnow P. Modulation of hepatitis C virus RNA abundance by a liver-specific MicroRNA. Science. 2005; 309:1577-1581. [PubMed: 16141076]

55. Lanford RE, Hildebrandt-Eriksen ES, Petri A, Persson R, Lindow M, Munk ME, Kauppinen S, Orum H. Therapeutic Silencing of MicroRNA-122 in Primates with Chronic Hepatitis C Virus Infection. Science. 2010; 327:198-201. [PubMed: 19965718]

56. Song E, Lee SK, Wang J, Ince N, Ouyang N, Min J, Chen J, Shankar P, Lieberman J. RNA interference targeting Fas protects mice from fulminant hepatitis. Nat Med. 2003; 9:347-351. [PubMed: 12579197]

57. De Paula D, Bentley MV, Mahato RI. Hydrophobization and bioconjugation for enhanced siRNA delivery and targeting. Rna. 2007; 13:431-456. [PubMed: 17329355]

58. Hacein-Bey-Abina S, Von Kalle C, Schmidt M, McCormack MP, Wulffraat N, Leboulch P, Lim A, Osborne CS, Pawliuk R, Morillon E, Sorensen R, Forster A, Fraser P, Cohen JI, de Saint Basile G, Alexander I, Wintergerst U, Frebourg T, Aurias A, Stoppa-Lyonnet D, Romana S, RadfordWeiss I, Gross F, Valensi F, Delabesse E, Macintyre E, Sigaux F, Soulier J, Leiva LE, Wissler M, Prinz C, Rabbitts TH, Le Deist F, Fischer A, Cavazzana-Calvo M. LMO2-associated clonal T cell proliferation in two patients after gene therapy for SCID-X1. Science. 2003; 302:415-419. [PubMed: 14564000]

59. Davis ME. The First Targeted Delivery of siRNA in Humans via a Self-Assembling, Cyclodextrin Polymer-Based Nanoparticle: From Concept to Clinic. Mol Pharmaceut. 2009; 6:659-668.

60. Heidel JD, Liu JYC, Yen Y, Zhou BS, Heale BSE, Rossi JJ, Bartlett DW, Davis ME. Potent siRNA inhibitors of ribonucleotide reductase subunit RRM2 reduce cell proliferation in vitro and in vivo. Clinical Cancer Research. 2007; 13:2207-2215. [PubMed: 17404105]

61. Heidel JD, Yu ZP, Liu JYC, Rele SM, Liang YC, Zeidan RK, Kornbrust DJ, Davis ME. Administration in non-human primates of escalating intravenous doses of targeted nanoparticles containing ribonucleotide reductase subunit M2 siRNA. P Natl Acad Sci USA. 2007; 104:57155721.

62. Lopez-Fraga M, Martinez T, Jimenez A. RNA Interference Technologies and Therapeutics From Basic Research to Products. BioDrugs. 2009; 23:305-332. [PubMed: 19754220]

63. Mccormick F. Ras Gtpase Activating Protein - Signal Transmitter and Signal Terminator. Cell. 1989; 56:5-8. [PubMed: 2535967] 
64. Lim LP, Lau NC, Garrett-Engele P, Grimson A, Schelter JM, Castle J, Bartel DP, Linsley PS, Johnson JM. Microarray analysis shows that some microRNAs downregulate large numbers of target mRNAs. Nature. 2005; 433:769-773. [PubMed: 15685193]

65. Braun A. Biosafety in handling gene transfer vectors. Curr Protoc Hum Genet. 2006; Chapter 12(Unit 12):11.

66. Grimm D, Streetz KL, Jopling CL, Storm TA, Pandey K, Davis CR, Marion P, Salazar F, Kay MA. Fatality in mice due to oversaturation of cellular microRNA/short hairpin RNA pathways. Nature. 2006; 441:537-541. [PubMed: 16724069]

67. van de Wetering M, Oving I, Muncan V, Pon Fong MT, Brantjes H, van Leenen D, Holstege FC, Brummelkamp TR, Agami R, Clevers H. Specific inhibition of gene expression using a stably integrated, inducible small-interfering-RNA vector. Embo Rep. 2003; 4:609-615. [PubMed: 12776180]

68. Czauderna F, Santel A, Hinz M, Fechtner M, Durieux B, Fisch G, Leenders F, Arnold W, Giese K, Klippel A, Kaufmann J. Inducible shRNA expression for application in a prostate cancer mouse model. Nucleic Acids Res. 2003; 31:e127. [PubMed: 14576327]

69. Kappel S, Matthess Y, Kaufmann M, Strebhardt K. Silencing of mammalian genes by tetracyclineinducible shRNA expression. Nat Protoc. 2007; 2:3257-3269. [PubMed: 18079726]

70. Zhou X, Ruan J, Wang G, Zhang W. Characterization and identification of microRNA core promoters in four model species. PLoS Comput Biol. 2007; 3:e37. [PubMed: 17352530]

71. Lee Y, Kim M, Han J, Yeom KH, Lee S, Baek SH, Kim VN. MicroRNA genes are transcribed by RNA polymerase II. Embo J. 2004; 23:4051-4060. [PubMed: 15372072]

72. Morin RD, O’Connor MD, Griffith M, Kuchenbauer F, Delaney A, Prabhu AL, Zhao Y, McDonald H, Zeng T, Hirst M, Eaves CJ, Marra MA. Application of massively parallel sequencing to microRNA profiling and discovery in human embryonic stem cells. Genome Res. 2008; 18:610-621. [PubMed: 18285502]

73. Ryan BM, Robles AI, Harris CC. Genetic variation in microRNA networks: the implications for cancer research. Nat Rev Cancer. 2010; 10:389-402. [PubMed: 20495573] 

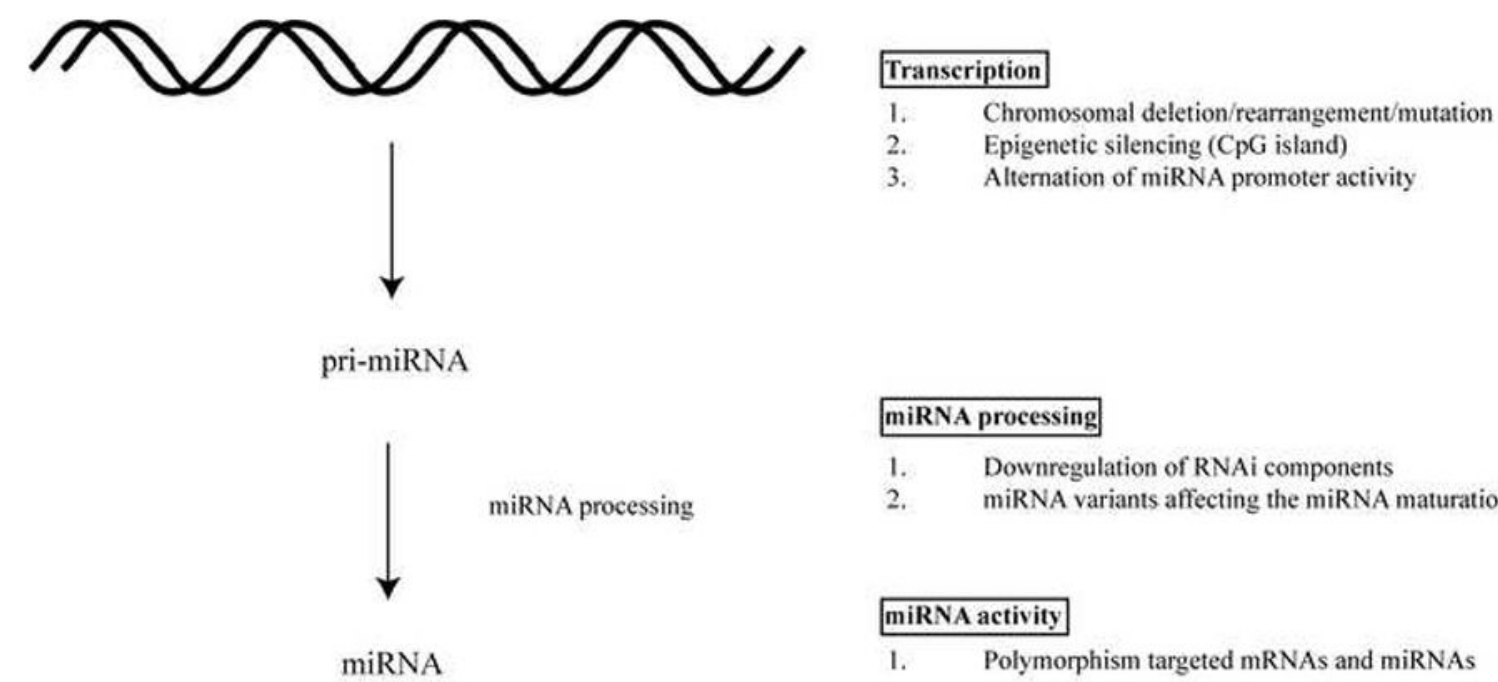
miRNA processing

1. Downregulation of RNAi components

2. miRNA variants affecting the miRNA maturation

miRNA activity

1. Polymorphism targeted mRNAs and miRNAs

Figure 1. Modulation of RNAi activity in eukaryotes at different levels

A) miRNAs are processed from precursor pri-, pre-, miRNA that contain stem-loop structure. The genes encoding miRNAs are regulated by their own promoters and regulatory elements $(70,71)$. The expression levels of miRNA precursor can be regulated at the transcriptional level by (1) Chromosomal deletion or translocation of regions containing miRNA genes. (2) Epigenetic silencing of regions containing miRNAs. (3) Alteration in the miRNA promoter activity. B) Functional miRNAs require a series of processing steps. (1) Downregulation of the RNAi components including Dicer, Drosha, Exportin 5, TRBP and Ago2 impairs the miRNA maturation process and has been correlated with cancer development (14-21). (2) miRNA structural variants with sequence changes at the processing-cleavage sites affect the ribonuclease activity of Drosha and Dicer (72). C) Mutations associated with sequence changes in miRNAs and miRNA target sites can affect the effectiveness of the gene silencing activity. (1) Polymorphisms, including SNP and potential deaminations of miRNAs and their targeted mRNAs have been detected in various cancers (73). 


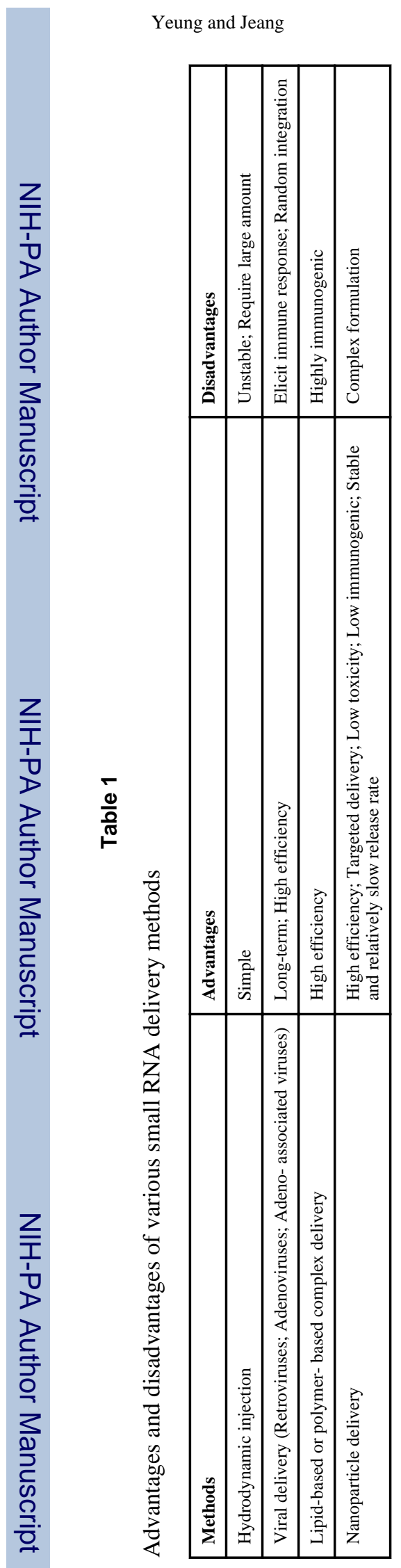

Page 12 


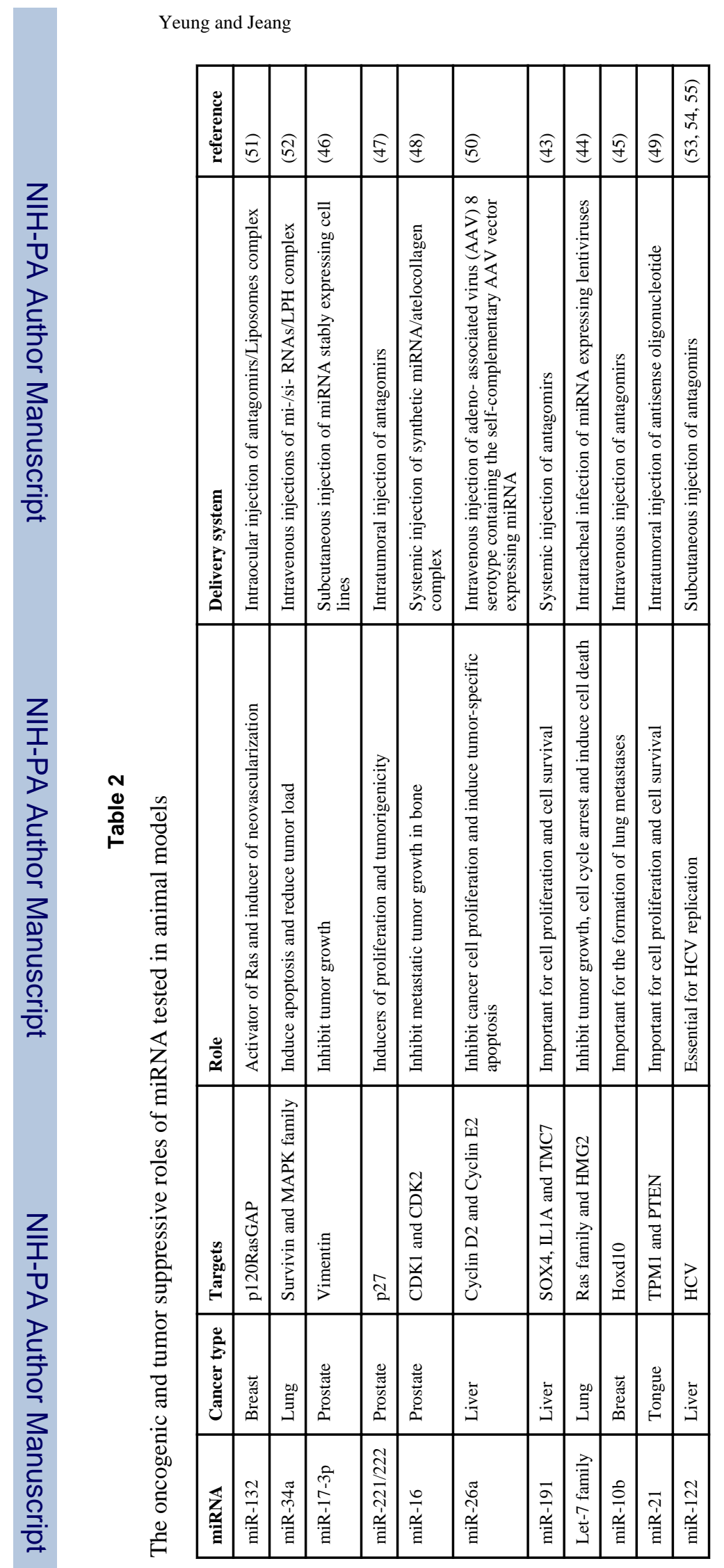

Pharm Res. Author manuscript; available in PMC 2012 July 25. 